\title{
Validation of Best Practice for Barley Production on Acid Soils of Central and Western Highland of Ethiopia: Effect of Liming on Ameliorating Soil Acidity and Soil P - Availability
}

\author{
Derib Kifle $^{1} \quad$ Adisalem Anteneh $^{1} \quad$ Fikadu Mosisa $^{1} \quad$ Getahun Dereje $^{1}$ \\ Temesgen Dessalegn ${ }^{2} \quad$ Ayalew Adela ${ }^{1}$ \\ 1. Holeta Agricultural Research Center, P O box 31, Holeta, Ethiopia \\ 2. Ethiopian Institute of Agricultural Research, P.O.Box 2003, Addis Ababa, Ethiopia
}

\begin{abstract}
A field experiment was conducted during 2018 cropping season at two locations (Welmera and Jeldu) in the central and western part of Ethiopia to verify the effect of lime in ameliorating soil acidity, $\mathrm{P}$ availability and barley productivity. Two barley production practices: $1.5 * \mathrm{EA}(\mathrm{t} / \mathrm{ha})$ of lime with $69 \mathrm{~kg} / \mathrm{ha} \mathrm{P}_{2} \mathrm{O}_{5}$ and a farmer's practice with no lime as a control were tested using a two plot design approach with 9 replication using farmers as replicates. Laboratory soil analytical results of both study areas showed that the soils are strongly acidic in reaction with low $\mathrm{P}$ content. Application of lime resulted in significant changes in some chemical properties of the soils in both locations. Soil acidity components such as soil pH, Exchangeable acidity, and Exchangeable Al were improved due to the application of lime and maximum and minimum values of these parameters were recorded. Availability of $\mathrm{P}$, growth parameters, yield and yield components were significantly increased with application of lime at the two locations. Dry biomass weight increment up to $79.4 \%$ and grain yield advantage of $40 \%$ was recorded due to liming at Rob Gebeya kebele of welmera district. Similarly, 233\%, 205\% and $17.3 \%$ rise was observed in dry biomass, grain yield and 1000 seed weight over the conventional farmer's practice/control/ respectively at Ento dale and shikute kebele of Jeldu district. According to the result of the current study, application of lime to acid soils led to slightly higher $\mathrm{pH}$, significant decrease in Exchangeable acidity and a marked development in available soil phosphorus level as related to the non amended soil confirming and demonstrating the fact that applying lime in acidic soil maximize the availability of nutrients especially phosphorus in the soil which is very important for better performance of crops.
\end{abstract}

Keywords: Soil acidity, Element toxicity, Nutrient availability, Crop productivity.

DOI: $10.7176 /$ JNSR/9-14-01

Publication date:July $31^{\text {st }} 2019$

\section{Introduction}

A decline in soil fertility implies either decline in the levels of some important soil properties such as soil organic carbon, pH, Cation Exchange Capacity (CEC), and plant nutrients or increment in the content of certain mineral nutrients levels that are toxic to plants. In the broadest sense, soil fertility decline includes nutrient depletion and nutrient mining (larger removal than addition of nutrients), acidification (decline in $\mathrm{pH}$ of the soil beyond the level of tolerance of most crops), the loss of Organic Matter (OM) due to poor crop residue management, and an increase in toxic elements such as aluminum (Al) and other toxic elements (Hartemink, 2003).

In the tropics the soil acidity is aggravated by leaching or/and continuous removal of basic cations through crop harvest. At pH below 5.5, aluminum is soluble in water and becomes the dominant ion in the soil solution. In acid soils, excess aluminum primarily injures the root apex and inhibits root elongation (Sivaguru and Horst 1998). The poor root growth leads to reduced water and nutrient uptake, and consequently crops grown on acid soils are confronted with poor nutrients and water availability. The net effect of which is reduced growth and yield of crops (Wang et. al., 2006; Tisdale et. al., 1985).

Soil acidity is expanding both in scope and magnitude in Ethiopia severely limiting crop production. In some barley and wheat growing areas of central and southern Ethiopia, farmers have shifted to producing oats which is more tolerant to soil acidity than wheat and barley. It is becoming a serious threat to crop production in most highland of Ethiopia in general and in Western Oromia and SNNPR in particular. Currently, it is estimated that about $40 \%$ of the total arable land of Ethiopia is affected by soil acidity (Abdenna et. al., 2007; Taye, 2007; Desta, 1988). Soil acidity affects the growth of crops because acidic soil contain toxic levels of aluminum and manganese and characterized by deficiency of essential plant nutrients such as $\mathrm{P}, \mathrm{Ca}, \mathrm{K}, \mathrm{Mg}$, and Mo (Wang et. al., 2006; Tisdale et. al., 1985). The cause of soil acidity could be the type of parent materials from which the soil are formed, leaching of base forming cations, continuous use of acid forming fertilizers such as Urea and DAP (Cook, 1982).

Barley (Hordeum vulgare L.) is the dominant cereal crop grown in the high lands of Ethiopia where soil acidity is raging. Barley production covers a total area of 1.02 million ha with a national average productivity of $1.87 \mathrm{t} / \mathrm{ha}$ (CSA, 2014). Soil acidity is considered to be one of the major bottlenecks to barley production in the highlands of Ethiopia. The problem still persists and has not been addressed sufficiently. Consequently, small 
holder farmers in the highlands of the country have almost given up barley production due to the severe soil acidity condition (Hailu and Getachew, 2011). Farmers in these areas are not encouraged to apply P fertilizer due to low response of crops to $\mathrm{P}$ application as a result of its fixation by $\mathrm{Al}$ and $\mathrm{Fe}$ to form insoluble phosphates, hence reducing P availability to plants (Kamprath, 1984). Phosphorus deficiency often, therefore, occurs simultaneously with Al toxicity in these soils. Efforts to ameliorate the ruinous effects of soil acidity must therefore be accompanied by measures to increase available $\mathrm{P}$ in soils. Addition of lime to acid soils has long been widely adopted as, the amelioration strategy for many years to improve crop production which is rarely used in Ethiopia.

A field experiment was conducted in the previous years to evaluate effects of lime application to acid soils on grain yield of some cereal crops in selected acid affected areas of the country. The results of the experiments showed that application of lime could sustainably enhance crop production and improve soil acidity on soils of the experimental areas. The objective of this study was therefore, to verify the effects of lime on barely grain yield and selected soil chemical properties in. other parts of Western Ethiopia with similar agro ecology and soil acidity intensity.

\section{Materials and methods \\ Description of the study area}

The study was conducted during 2018 main cropping seasons at Rob Gebeya kebele in Welmera district and at Ento Dalle, Tullu Gura, Serity and Shikute kebeles of Jeldu district in central and western part of Ethiopia respectively. The test sites were selected on the basis of soil acidity level which should have $\mathrm{pH}$ values lower than 5.5 , with no previous liming history. Welmera district is located at $8^{0} 50^{\prime}$ to $09^{0} 20^{\prime} \mathrm{N}$ and $38^{0} 20^{\prime}$ to $38^{0} 40^{\prime} \mathrm{E}$ at an altitude of 2400 meters above sea level (Figure 1). Its mean annual rainfall is $1044 \mathrm{~mm}$. Mean maximum and a minimum temperature are 22 and $6.1^{\circ} \mathrm{C}$, respectively with mean relative humidity of $60.6 \%$ (HARC, 2017). The main rainy season is from June to September and accounts for $70 \%$ of the annual rainfall. The environment is seasonally humid and the major soil types are Nitisols, fluvisols, and vertisols. Jeldu district is positioned on longitude $9^{\circ} 05^{\prime} \mathrm{N}$, latitude $38^{\circ} 36^{\prime} \mathrm{E}$ at altitude ranging from $1900 \mathrm{~m}$ to $3206 \mathrm{~m}$ asl, in western highlands of Ethiopia (Figure 1). The district obtain an average annual rainfall ranging from $218 \mathrm{~mm}$ to $1699 \mathrm{~mm}$ with bimodal pattern of distribution that extends from mid of April to mid of October with peak rainfall in mid of July to end of August. The commonest soils of the area are brown soils with alic nature. Some of the chemical characteristics of soils of the experimental sites are presented in Table 1
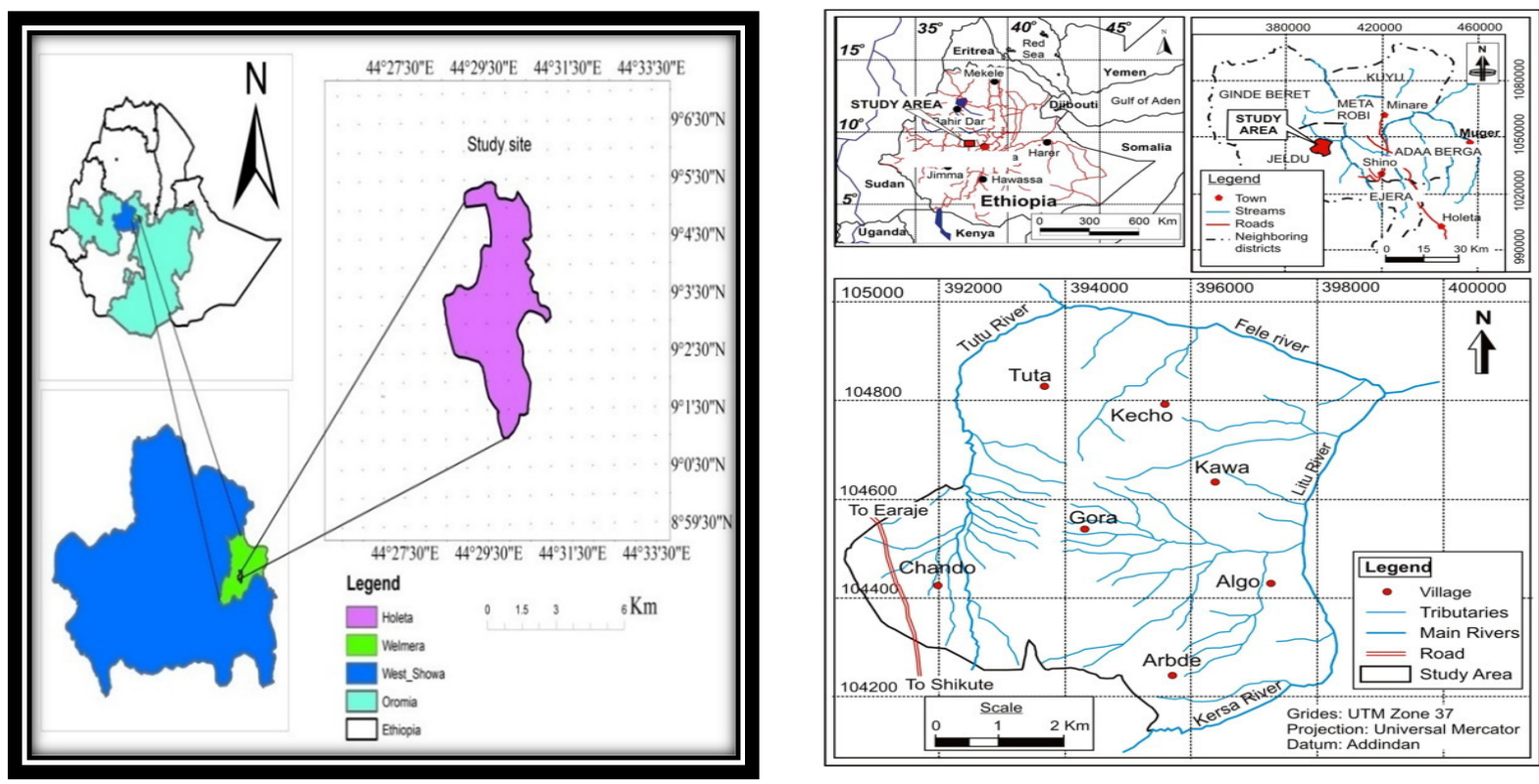

Figure 1. Location map of experimental sites in Welmera and Jeldu districts

\section{Experimental materials}

\section{Liming and Planting}

The liming material used in the experiment was ground limestone of standard particle size (fine enough to pass a U.S. Standard No. 8 sieve) and CCE (Calcium Carbonate Equivalent) of 90\% confirmed by laboratory test. Di ammonium Phosphate (DAP) and urea were used as inorganic fertilizer sources. The test crop used in the experiment is food barley variety BH-1307, which was released recently by Holeta Agricultural Research Centre. 


\section{Soil sampling and analysis}

Ten and five sub samples were collected from uniform area using a zigzag pattern to make a representative composite soil sample using an auger from a surface layer at depth of $20 \mathrm{~cm}$ from the whole experimental field before liming and from each treatment plot after harvesting respectively (Darrryl, 2000). The collected soil samples were air-dried, ground and sieved using a $2 \mathrm{~mm}$ size. The prepared soil samples were analysed following the standard laboratory procedure where Soil $\mathrm{pH}$ in water was measured at 1:2.5 soils to water ratio and the value was read using a combined glass electrode $\mathrm{pH}$ mete (van Reeuwijk, 1992). Exchangeable acidity was determined by base titration method saturating the soil samples with $1 \mathrm{M} \mathrm{KCl}$ solution and titrating with $0.01 \mathrm{M} \mathrm{NaOH}$ as described by (Rowell D, 1994). Exchangeable Al was determined from aqueous solutions extracted by $1 \mathrm{M} \mathrm{KCl}$ and $\mathrm{NaF}$ and titrated with $0.01 \mathrm{M} \mathrm{HCl}$. Available soil phosphorus was extracted by the Bray II procedure (Bray and Kurtz, 1945) and determined calorimetrically by spectrophotometer. Lime requirement of the soil was calculated based on its exchangeable acidity $\left(\mathrm{Al}^{+3}\right.$ plus $\left.\mathrm{H}^{+1}\right)$ and bulk density with in $0.15 \mathrm{~m}$ depth of the soil adapted from (Kamprath, 1984).

$\mathrm{LR}, \mathrm{CaCO}_{3}(\mathrm{~kg} / \mathrm{ha})=\left[\frac{\mathrm{cmolEA} / \mathrm{kg} \text { of soil } * 0.15 \mathrm{~m}^{*} 10^{4} \mathrm{~m}^{2} * \text { B.D. }\left(\mathrm{Mg} / \mathrm{m}^{3}\right) * 1000}{2000}\right]$
$* 1.5$

\section{Experimental design and Treatments}

Two barley production practices were tested using a two plot design approach with 9 replication using farmers as replicates. The experimental fields were divided in to two parts where one part was treated with the research recommended rate of lime as best practice of a model farmer and the other part was used as a control, representing the conventional practice followed by non-model farmer.

\section{Experimental procedure}

The study was conducted under rain-fed condition on gross plot size of $10 \mathrm{~m} \times 10 \mathrm{~m}$. Lime was applied by spreading on a well-ploughed and pulverized seed bed incorporating it into the soil at plough depth one month before planting. At planting, the barley seeds were sown with rate of $125 \mathrm{~kg}$ ha-1 by drilling at spacing of $20 \mathrm{~cm}$ between rows to a shallow depth of about $5 \mathrm{~cm}$ and covered with the soil at mid of June along with the recommended rate of fertilizer (150 kg ha-1 DAP and $130 \mathrm{~kg}$ ha-1 urea). The entire dose of DAP was applied at planting, while the recommended $\mathrm{N}$ rate $(46 \mathrm{~kg} / \mathrm{ha})$ was applied in split, viz: half at sowing and the remaining half side dressed at tillering stage of barley. Subsequent agronomic activities following the emergence of the seedlings such as weeding, harvesting, and threshing was performed according to the locally adopted methods. Crop data collection was undertaken when the plant reached early stage of maturity and at harvesting. Ten plants were randomly selected from the middle rows for data collection on plant height at maturity while the whole harvestable rows were used for collecting data on dry biomass weight and grain yield at harvesting. The height of ten randomly selected plants was measured from the ground to top of the plant and the means were recorded as plant height $(\mathrm{cm})$. The above ground dry biomass was measured near physiological maturity stage before harvesting from 10 randomly selected plants. Total biological yield per plot area was calculated from the harvestable rows based on biomass of the sampled plants. Grain yield was recorded from each net plot area where the moisture is adjusted to standard moisture content of $12 \%$ as designated for cereals according to the guidelines by Biru Abebe (1979). 1000 grain weight was measured in grams after threshing.

\section{Statistical analysis}

The collected data were subjected to analysis using Inferential (inductive) statistics employing SPSS (PASW) software where test of the difference between two means was done by Matched (paired) t-test

\section{Result and discussion}

\section{Threshold chemical properties of the soil of the experimental areas}

Laboratory analytical results of selected properties of the soil of experimental site before lime application are presented in Table 1. The results showed that the soils of the experimental fields found in both districts were in the range of very strongly acidic to extremely acidic in reaction with exchangeable acidity highly dominated by $\mathrm{Al}^{+3}$ according to the rating done by Landon (1991). The Bray available P level of the soil is very low according to Jones (2003) and is below the critical level (Tekalign, 1991) 
Table 1. Soil acidity level and available $\mathrm{P}$ content of the soil before liming

\begin{tabular}{lllllll}
\hline $\begin{array}{l}\text { Loc. } \\
\text { code }\end{array}$ & District & PA & pH. & $\begin{array}{l}\text { Ex.Acidity } \\
\mathbf{m e q} / \mathbf{1 0 0 g}\end{array}$ & $\begin{array}{c}\text { Ex. Al } \\
\mathbf{m e q} / \mathbf{1 0 0 g}\end{array}$ & $\begin{array}{l}\text { Av. P in } \\
\mathbf{p p m}\end{array}$ \\
\hline 1 & Welmera & Rob Gebeya & 4.95 & 1.33 & 0.93 & 5.06 \\
2 & Welmera & Rob Gebeya & 4.69 & 2.15 & 1.71 & 5.98 \\
3 & Welmera & Rob Gebeya & 4.60 & 1.99 & 1.40 & 18.76 \\
4 & Welmera & Rob Gebeya & 4.72 & 2.12 & 1.55 & 41.29 \\
5 & Welmera & Rob Gebeya & 4.91 & 1.96 & 1.71 & 4.72 \\
6 & Welmera & Rob Gebeya & 4.92 & 1.39 & 1.16 & 5.14 \\
7 & Welmera & Rob Gebeya & 4.95 & 1.46 & 1.16 & 10.35 \\
8 & Jeldu & Serity & 4.44 & 3.99 & 1.09 & 11.59 \\
9 & Jeldu & Ento Dalle & 4.59 & 3.40 & 0.93 & 7.90 \\
10 & Jeldu & Tullu Gura & 4.49 & 4.07 & 1.71 & 11.58 \\
11 & Jeldu & Shikute & 4.28 & 4.98 & 1.16 & 7.20 \\
\hline
\end{tabular}

Impact of liming on yield and yield related agronomic traits of barley

Analysis of agronomic data indicated that the research recommended lime application significantly affected the growth and yield component of barley (Table 2, 3, 4\&5). The yield and related agronomic responses were found more pronounced with application of lime where lime treatment gave a dry biomass weight increment up to $79.4 \%$ and grain yield advantage up to $40 \%$ at Rob Gebeya kebele of welmera district. Similarly, $156 \%$ and $205 \%$ grain yield rise was observed over the conventional farmer's practice/control/ at Ento dale and shikute kebele of Jeldu district respectively. The marked increase in barley yield and related attributes in response to lime application may be ascribed to the synergies of creating good soil condition that came in to play due to neutralization of soil acidity and reduction of element toxicity.

The increase in plant height, dry biomass weight and 1000 seed weight can be attributed to the general improvement of the soil environment in terms of decreased acidity, increased availability of plant nutrients and enhanced microbial activities especially at the rhizosphere and root length with decrease in soil acidity due to application of lime. The improved soil environment due to the inputs, favours optimal functions of microbial activities such as mineralisation process (Jones et al., 2005; Harrison et al., 2008). Bado and Batiano (2004) reported that integration of liming with inorganic fertilizer sources result into synergy, and improved conservation and synchronization of nutrient release, and crop demand leading to higher yields. Liming of acidic soils improves the yields of most crops, the relationship between yield and soil $\mathrm{pH}$ differs between crops and is influenced by soil type (Fageria, 2008). For example, in the UK, potato crops generally achieve maximal yields at a lower soil $\mathrm{pH}$ than other crops such as wheat, beans or canola, although, the magnitude of this difference depends on field site Table 2. Effects of lime application on plant height $(\mathrm{cm})$ of barley in districts of central highland of Ethiopia

\begin{tabular}{lllllllllllll}
\hline Farmer & $\mathbf{1}$ & $\mathbf{2}$ & $\mathbf{3}$ & $\mathbf{4}$ & $\mathbf{5}$ & $\mathbf{6}$ & $\mathbf{7}$ & $\mathbf{8}$ & $\mathbf{9}$ & $\mathbf{1 0}$ & $\mathbf{1 1}$ & Sum \\
\hline No lime & 114 & 114 & 111 & 88 & 110 & 91 & 86 & 92 & 76 & 84 & 91 \\
Limed & 116 & 124 & 118 & 96 & 116 & 98 & 93 & 115 & 105 & 117 & 111 \\
Difference $(\mathrm{d})$ & 2 & 10 & 7 & 8 & 6 & 7 & 7 & 23 & 29 & 33 & 20 & 152 \\
$\begin{array}{l}\text { Mean of the difference }(d) \\
(d-d) 2\end{array}$ & 13.8 & & & & & & & & & & & \\
& 140 & 14.6 & 46.5 & 33.9 & 61 & 46 & 46 & 84 & 230 & 368 & 38.2 & 1109 \\
\hline Var. of the difference $\left(\mathrm{Sd}^{2}\right)$ & 110.9 & & & & & & & & & & & \\
Test statistics $(\mathrm{tc})$ & 4.15 & & & & & & & & & & \\
Table t value & 2.228 & & & & & & & & & & \\
\hline
\end{tabular}

Table 3. Effects of liming on dry biomass weight (tons ha ${ }^{-1}$ ) of barley in districts of central highland of Ethiopia

\begin{tabular}{lllllllllllll}
\hline Farmer & $\mathbf{1}$ & $\mathbf{2}$ & $\mathbf{3}$ & $\mathbf{4}$ & $\mathbf{5}$ & $\mathbf{6}$ & $\mathbf{7}$ & $\mathbf{8}$ & $\mathbf{9}$ & $\mathbf{1 0}$ & $\mathbf{1 1}$ & Sum \\
\hline No lime & 8.6 & 13.2 & 7.3 & 5.2 & 10.7 & 5.5 & 4.1 & 3.9 & 4.3 & 2.0 & 7.0 & \\
lime & 9.6 & 14.9 & 13.1 & 5.8 & 10.8 & 5.8 & 4.5 & 13.0 & 10.4 & 9.4 & 13.0 & \\
Differ(d) & 1.0 & 1.8 & 5.8 & 0.6 & 0.1 & 0.3 & 0.4 & 9.1 & 6.1 & 7.4 & 6.0 & 38.4 \\
Mean of the diff $(d)$ & 3.5 & & & & & & & & & & & \\
$(\mathrm{~d}-d) 2$ & 6.2 & 3.0 & 5.3 & 8.4 & 11.5 & 10.5 & 9.6 & 31.5 & 6.6 & 14.9 & 6.3 & 114 \\
\hline Var. of the diff $\left(\mathrm{Sd}^{2}\right)$ & 11.37 & & & & & & & & & $1 / / /$ & & \\
Test statistics $(\mathrm{tc})$ & 3.43 & & & & & & & & & & \\
Table t value & 2.228 & & & & & & & & & & & \\
\hline
\end{tabular}


Table 4. Effects of liming on grain yield (tons ha ${ }^{-1}$ ) of barley in districts of central highland of Ethiopia

\begin{tabular}{lllllllllllll}
\hline Farmer & $\mathbf{1}$ & $\mathbf{2}$ & $\mathbf{3}$ & $\mathbf{4}$ & $\mathbf{5}$ & $\mathbf{6}$ & $\mathbf{7}$ & $\mathbf{8}$ & $\mathbf{9}$ & $\mathbf{1 0}$ & $\mathbf{1 1}$ & Sum \\
\hline No lime & 3.2 & 5.6 & 3.0 & 2.2 & 4.1 & 2.3 & 1.6 & 1.9 & 1.6 & 1.6 & 2.7 & \\
lime & 3.6 & 6.2 & 4.2 & 2.4 & 4.3 & 2.5 & 2.4 & 5.8 & 4.2 & 3.1 & 4.8 & \\
Differ(d) & 0.4 & 0.6 & 1.2 & 0.3 & 0.2 & 0.2 & 0.8 & 3.9 & 2.5 & 1.5 & 2.1 & 13.8 \\
Mean of the diff $(d)$ & 1.3 & & & & & & & & & & & \\
$(\mathrm{~d}-d) 2$ & 0.7 & 0.4 & 0.0 & 1.0 & 1.1 & 1.2 & 0.2 & 6.9 & 1.7 & 0.1 & 0.8 & 13.9 \\
\hline Variance of the diff $\left(\mathrm{Sd}^{2}\right)$ & 1.39 & & & & & & & & & & & \\
Test statistics (tc) & 3.53 & & & & & & & & & & & \\
Table t value & 2.228 & & & & & & & & & & &
\end{tabular}

Table 5. Effects of liming on 1000 grain weight (grams) of barley in districts of central highland of Ethiopia

\begin{tabular}{lllllllllllll}
\hline Farmer & $\mathbf{1}$ & $\mathbf{2}$ & $\mathbf{3}$ & $\mathbf{4}$ & $\mathbf{5}$ & $\mathbf{6}$ & $\mathbf{7}$ & $\mathbf{8}$ & $\mathbf{9}$ & $\mathbf{1 0}$ & $\mathbf{1 1}$ & Sum \\
\hline No lime & 47.6 & 50 & 45 & 39 & 44.8 & 39.2 & 44.5 & 44.8 & 48 & 45 & 54 & \\
Limed & 50.4 & 52 & 48 & 46 & 47.6 & 44 & 46.2 & 50 & 54 & 52.8 & 58 & \\
Differ.(d) & 2.8 & 2 & 3 & 7 & 2.8 & 4.8 & 1.7 & 5.2 & 6 & 7.8 & 4 & 47.1 \\
Mean of the diff. $(d)$ & 4.28 & & & & & & & & & & & \\
$(\mathrm{~d}-d) 2$ & 2.19 & 5.2 & 1.64 & 7.40 & 2.19 & 0.27 & 6.66 & 0.85 & 2.96 & 12.39 & 0.08 & 41.82 \\
\hline Var. of the diff. $\left(\mathrm{Sd}^{2}\right)$ & 4.18 & & & & & & & & & & & \\
Test statistics (tc) & 6.95 & & & & & & & & & & & \\
Table t value & 2.228 & & & & & & & & & & & \\
\hline
\end{tabular}

\section{The impacts of liming on soil processes: Soil acidity indices and phosphorus availability}

Results of soil $\mathrm{pH}$, exchangeable acidity and available $\mathrm{P}$ obtained from soil amended with lime in the experimental areas are presented in Table 6,7,8 \& 9. Lime treatment recorded higher value of some chemical property of the soil which translates up to nearly a $25 \%$ increase from the initial soil $\mathrm{pH}$ value and up to $600 \%$ and $154 \%$ in exchangeable acidity and available soil phosphorus respectively compared to the no input/no lime/ treatment (control). Generally, there was a gradual trend of $\mathrm{pH}$ increase with lime to the highest value of 5.43 obtained at Jeldu's experimental location. In comparison, it was observed that application of lime to acid soils led to slightly higher $\mathrm{pH}$ and a pronounced development in exchangeable acidity and available soil phosphorus level as related to the non amended soil. The result of the current verification trial showed that liming impacts on neutralising acidity changing the soil chemical balance is immense. Liming materials contain $\mathrm{Ca}^{2+}$ or $\mathrm{Mg}^{2+}$ cations (sometimes both) and their supply has a neutralizing effect displacing the $\mathrm{H}+$ in the soil solution. The same pattern was observed for the other soil chemical properties with significantly higher values.

The reductions in exchangeable $\mathrm{Al}$ and percent $\mathrm{Al}$ saturation of the soils were related to the increased soil $\mathrm{pH}$. The increment of plant available $\mathrm{P}$ content of the soils with lime application may be attributed to modification of soil environment $(\mathrm{pH})$ due to liming that intern gave rise to the release of the unavailable $\mathrm{P}$ which was previously fixed with $\mathrm{Al}$ and $\mathrm{Fe}$ at low soil $\mathrm{pH}$ condition. Therefore, agricultural liming materials added to soil is a profitable soil additive and it hydrolyzes $\mathrm{Al}$ and $\mathrm{Fe}$ ions that precipitated with $\mathrm{P}$. Hence, the precipitated phosphate ion released in to the soil solution thereby rendering the phosphate ion available for plant uptake. Similar observation was made by Shen et al. (1998) who reported that reclaiming acid soils by lime increased the soil $\mathrm{pH}$ which is mainly due to the neutralization of $\mathrm{Al}$ ion in the soil solution by hydroxyl $(\mathrm{OH})$ ion furnished by the hydrolysis reaction of the agricultural liming material added to the soils Liming and thus raising the $\mathrm{pH}$ of acidic soil across different land use systems generally provide more favourable environments for microbial activities and possibly results net mineralization of soil organic matter (Bardgett et al.1995). Similar explanation for the raised soil P value was given by Jokubauskaite et al, (2015) that related the raise to the intensified microbial activity at higher $\mathrm{pH}$ values, enhancing the mineralization processes in soil. Effect of liming on phosphate adsorption availability in acid soils was studied by Fageria, and Baligar, 2008 who concluded that the adsorption of phosphate by amphoteric soil surfaces generally decreased slowly as the $\mathrm{pH}$ increased from 4.0 to 7.0. They also stated that liming can increase phosphate availability by stimulating mineralization of soil organic phosphorus that occurs in a variety of chemical forms and can be released through mineralization processes mediated by soil organisms and plant roots 
Table 6. Effects of liming on Soil pH in districts of central highland of Ethiopia

\begin{tabular}{lllllllllllll}
\hline Farmer & $\mathbf{1}$ & $\mathbf{2}$ & $\mathbf{3}$ & $\mathbf{4}$ & $\mathbf{5}$ & $\mathbf{6}$ & $\mathbf{7}$ & $\mathbf{8}$ & $\mathbf{9}$ & $\mathbf{1 0}$ & $\mathbf{1 1}$ & Sum \\
\hline No lime & 4.82 & 4.65 & 4.82 & 4.65 & 4.96 & 4.93 & 4.88 & 4.44 & 4.63 & 4.73 & 4.33 & \\
Limed & 5.4 & 4.78 & 5.09 & 5.05 & 5.48 & 5.56 & 5.31 & 5.1 & 5.05 & 5.15 & 5.43 & \\
Difference(d) & 0.58 & 0.13 & 0.27 & 0.40 & 0.52 & 0.63 & 0.43 & 0.66 & 0.42 & 0.42 & 1.10 & 5.56 \\
Mean of the diff. $(d)$ & 0.51 & & & & & & & & & & & \\
$(\mathrm{~d}-d) 2$ & 0.00 & 0.14 & 0.06 & 0.01 & 0.00 & 0.01 & 0.01 & 0.02 & 0.01 & 0.01 & 0.35 & 0.63 \\
\hline Var. of the diff. $\left(\mathrm{Sd}^{2}\right)$ & 0.06 & & & & & & & & & & & \\
Test statistics $(\mathrm{tc})$ & 6.84 & & & & & & & & & & & \\
Table t value & 2.228 & & & & & & & & & & & \\
\hline
\end{tabular}

Table 7. Effects of liming on Soil Ex. Acidity (meq/100g soil) in districts of central highland of Ethiopia

\begin{tabular}{lllllllllllll}
\hline Farmer & 1 & 2 & 3 & 4 & 5 & 6 & 7 & 8 & 9 & 10 & 11 & Sum \\
\hline No lime & 0.96 & 3.30 & 1.73 & 1.52 & 0.99 & 0.84 & 1.06 & 5.17 & 4.42 & 6.46 & 5.50 & \\
Limed & 0.13 & 1.03 & 0.22 & 0.50 & 0.10 & 0.22 & 0.26 & 1.02 & 2.30 & 4.26 & 0.73 & \\
Difference(d) & 0.83 & 2.26 & 1.50 & 1.02 & 0.90 & 0.62 & 0.81 & 4.15 & 2.12 & 2.20 & 4.77 & 21.18 \\
Mean of the diff. $(d)$ & 1.93 & & & & & & & & & & & \\
$(\mathrm{~d}-d) 2$ & 1.06 & 0.16 & 0.13 & 0.71 & 0.93 & 1.53 & 1.11 & 5.25 & 0.07 & 0.12 & 8.46 & 19.52 \\
\hline Var. of the diff.(Sd $\left.{ }^{2}\right)$ & 1.95 & & & & & & & & & & & \\
Test statistics $(t c)$ & 4.35 & & & & & & & & & & & \\
Table t value & 2.228 & & & & & & & & & & & \\
\hline
\end{tabular}

Table 8.Effects of liming on Soil Ex. Aluminum (meq/100g soil) in districts of central highland of Ethiopia

\begin{tabular}{lllllllllllll}
\hline Farmer & $\mathbf{1}$ & $\mathbf{2}$ & $\mathbf{3}$ & $\mathbf{4}$ & $\mathbf{5}$ & $\mathbf{6}$ & $\mathbf{7}$ & $\mathbf{8}$ & $\mathbf{9}$ & $\mathbf{1 0}$ & $\mathbf{1 1}$ & Sum \\
\hline No lime & 0.66 & 2.14 & 1.38 & 1.36 & 0.74 & 0.62 & 0.78 & 4.04 & 3.57 & 4.97 & 4.27 & \\
Limed & 0.06 & 0.73 & 0.16 & 0.30 & 0.00 & 0.10 & 0.18 & 0.88 & 1.68 & 3.70 & 0.00 & \\
Difference (d) & 0.60 & 1.42 & 1.22 & 1.06 & 0.74 & 0.52 & 0.60 & 3.16 & 1.89 & 1.26 & 4.27 & 16.74 \\
Mean of the diff. $(d)$ & 1.52 & & & & & & & & & & & \\
$(\mathrm{~d}-d) 2$ & 1.59 & 0.20 & 0.41 & 0.63 & 1.26 & 1.80 & 1.59 & 1.69 & 0.00 & 0.36 & 5.82 & 15.34 \\
\hline Var. of the diff. $\left(\mathrm{Sd}^{2}\right)$ & 1.53 & & & & & & & & & & & \\
Test statistics (tc) & 4.08 & & & & & & & & & & & \\
Table t value & 2.228 & & & & & & & & & & & \\
\hline
\end{tabular}

Table 9. Effects of liming on Soil Av. Phosphorus (ppm) in central highland of Ethiopia

\begin{tabular}{lllllllllllll}
\hline Farmer & 1 & 2 & 3 & 4 & 5 & 6 & 7 & 8 & 9 & 10 & 11 & Sum \\
\hline No lime & 8.8 & 8.6 & 10.7 & 13.6 & 8.0 & 6.4 & 8.5 & 11.6 & 7.9 & 11.6 & 7.2 & \\
Limed & 10.6 & 11.2 & 24.4 & 27.2 & 10.0 & 9.0 & 10.3 & 14.4 & 13.1 & 13.5 & 18.3 & \\
Difference(d) & 1.8 & 2.6 & 13.6 & 13.6 & 2.0 & 2.6 & 1.8 & 2.8 & 5.2 & 1.9 & 11.1 & 59.0 \\
Mean of the diff. $(d)$ & 5.4 & & & & & & & & & & & \\
$(\mathrm{~d}-d) 2$ & 12.9 & 7.7 & 68.1 & 67.9 & 11.3 & 7.7 & 12.4 & 6.7 & 0.0 & 12.1 & 33.0 & 239.6 \\
\hline Var. of the diff. $\left(\mathrm{Sd}^{2}\right)$ & 24.0 & & & & & & & & & & & \\
Test statistics $(\mathrm{tc})$ & 3.63 & & & & & & & & & & & \\
Table t value & 2.228 & & & & & & & & & & & \\
\hline
\end{tabular}

\section{Conclusion and recommendations}

In the validation experiment conducted in the highlands of Welmera and Jeldu, there was a strong evidence $(\mathrm{t}=$ 2.228) that the soil acidity management intervention through liming improves barley productivity and soil chemical property. In this data set, liming improved dry biomass yield, grain yield and 1000 seed weight of barley up to $79.4 \%, 40 \%$ and $17.9 \%$ respectively at Rob Gebeya kebele of welmera district and showed a corresponding increment of the same up to $233 \%, 205 \%$ and $17.3 \%$ at the experimental sites found in Jeldu district.

The findings of the verification experiment support the idea that liming ameliorates soil acidity and improves soil chemical property making it favorable for the crop growth. There was a significant increase $(\mathrm{P}<0.05)$ in soil $\mathrm{pH}$ with the highest value (5.56) at test site of Welmera and (5.43) at that of Jeldu district. Exchangeable acidity decreased significantly $(\mathrm{P}<0.05)$ with lime application to as low as $0.73 \mathrm{meq} / 100$ gram soil at Jeldu which dropped by more than $500 \%$ when compared to the non limed control. However, the result of soil analysis suggest that the acidity level of most of the soil after liming is still high (Table 6) suggesting that there is still the need of more 
liming to reduce the intensity of the problem to give more reasonable yield. It was also observed that application of lime to acid soils led to slightly higher $\mathrm{pH}$ and a marked development in available soil phosphorus level as related to the non amended soil confirming and demonstrating the fact that applying lime in acidic soil maximize the availability of nutrients especially phosphorus in the soil which is very important for better performance of crops.

From the stand point of the observations of this study, the recommendation made by the authors is that further research undertakings in this line should be frequented. The study tested only calcite agricultural lime using commercial fertilizers; DAP and Urea as a source of $\mathrm{N}$ and $\mathrm{P}$, the only essential plant nutrient being used in Ethiopian agriculture to date. Therefore, more research needs to be carried out using other types of liming and fertilizer materials. In the intervening time, farmers in the other similar acid affected areas in the country should be encouraged to use lime to cope up with the current soil acidity challenges in boosting crop productivity.

\section{References}

Abdenna, D., Negassa, C.W. and Tilahun, G. 2007. Inventory of Soil Acidity Status in Crop Lands of Central and Western Ethiopia. "Utilisation of diversity in land use systems: Sustainable and organic approaches to meet human needs" Tropentag, October 9-11, 2007, Witzenhausen

Abstracts of international Symposium of the African Network (AfNet) of Tropical Soil Fertility Programme (TSBF) Institute of CIAT (17-21 May, 2004). Yaunde, Camerron. Pp 24.

Bado, V. and Batiano, A., (2004). Maize yields as affected by organic and mineral nitrogen management in the Guinean zone of Burkina Faso. In: Batiano et al, (eds). Improving human welfare and environmental conservation by empowering farmers to combat soil fertility degradation. Book of

Bardgett, R., Leemans, D., 1995. The short-term effects of cessation of fertiliser applications, liming, and grazing on microbial biomass and activity in a reseeded upland grassland soil. Biol. Fertil. Soils 19, 148-154.

Bardgett, R.D., Hobbs, P.J., Frostegård, Å., 1996. Changes in soil fungal:bacterial biomass ratios following reductions in the intensity of management of an upland grassland. Biol. Fertil. Soils 22, 261-264.

BirruAbebe, 1979. Agricultural Field Experiment Management manual Part III. IAR ( Institute of Agricultural research, Addis Ababa, Ethiopia.

Bray and Kurtz, 1945.Determination of total, organic and available form of phosphorus in soils. Soil Sci.59:39-45

Central Statistical Agency (CSA) (2014). Agricultural Sample Survey Report on area and production of major crops. (private peasant holdings, Meher Season). V1. Statistical Bulletin. Addis Ababa, Ethiopia

Darryl D. W, 2000.Sampling soil for fertilizer and lime recommendations. Extension Bulletin E498, Crop and Soil Sciences Department, Michigan University.

Desta, B.1987. Soil Science Research in Ethiopia: A Review .Proceedings of the first Soil Science Research Review Workshop, 11-14 February 1986, Addis Ababa, IAR, Addis Ababa.pp

Fageria, N.K., Baligar, V.C., 2008. Ameliorating soil acidity of tropical oxisols by liming for sustainable crop production.Advances in Agronomy. Academic Press, pp. 345-399.

Fageria, N.K., Castro, E.M., and Baligar, V.C., (2004). Response of upland rice genotypes to soil acidity. In: Wilson et al, (eds). The Red Soils of China: Their Nature, Management and Utilization. Pp. 219-237. Kluwer Academic Publishers, Dordrecht.

Hailu R, Getachew A (2011). Potential and limitations of acid soils in the highlands of Ethiopia: a review. In: Mulat, B. and Grando, S. (eds.). Proceedings of the 2nd National Barely Research and Development Review Workshop. HARC, Holetta, Ethiopia pp. 103-112

Harrison K.A, Bol R, and Bardgett R.D., (2008). Do plant species with different growth strategies vary in their ability to compete with soil microbes for chemical forms of nitrogen? Soil Biology and Biochemistry, 40: 228-237.

Haynes RJ (1992) Effects of liming on phosphate availability in acid soils. Plant and Soil 68: 289-308.

Hossner, L.R. and A.S.R. Juo, 1989.Mineralogical and chemical properties of acid soils. In: BernhandHintze and C.R. Ellot (eds.). First training Workshop on acid Tropical Soils Management and Land Development practice. 28 August-11 September, 1988. IBSRAM Technical Notes, 2: 59-78

Jokubauskaite I, Karcauskiene D, Antanaitis S, Mazvila J, Slepetiene A, Končius D, Piaulokaite-Motuziene L. The distribution of phosphorus forms and fractions in Retisol under diferent soil liming management.Zemdirb Agric. 2015;102:251-6.

Jones D.L, Shannon D, Junvee-Fortune T, and Farrar J.F., (2005). Plant capture of free amino acids is maximized under high soil amino acid concentrations. Soil Biology and Biochemistry, 37: 179-181.

Jones. J.B, 2003.Agronomic Hand book : Management of Crops Soils and Their Fertility.CRC Press LLC, Boca Raton, Florida, USA.482p

Kamprath EJ (1984). Crop Response to lime in the tropics. In: Adams, F. (eds.). Soil Acidity and Liming. Agronomy Madison, Wisconsin, USA 12:349-368.

Osei, B.A., 1995. Effects of different lime application rates and time on some chemical properties of an acid soil 
in Ghana. Soil Use and Management, 11: 25-29.

Rowell D., 1994. Soil Science: Method and Applications. Addison, Wesley, England: Longman Scientific and Technical, Longman Group UK Limited.

Shen J, Yuan L, Zhang J, Li H, Bai Z, Chen X, Zhang W, Zhang F. Phosphorus dynamics: from soil to plant. Plant Physiol. 2011;156(997):1005.

Shen, S., E.P. Gary, J.J. Hasset and J.W. Stucki, 1998., 1998 Acidity and aluminum toxicity caused by iron oxidation around anode bars. Soil Sci., 163: 657-664.

Sivaguru M and Horst, W. J. 1998. The distal part of the transition zones is the most aluminum-sensitive apical root zone of maize. Plant Physiology. 116, 155-163.

Taye, B. 2007. An overview of acid soils their management in Ethiopia paper presented in the third International Workshop on water management (Wterman) project, September, 19-21, 2007, Haramaya, Ethiopia.

TekalignTadese, 1991. Soil plant water, fertilizer, animal manure and compost analysis working document, No 13.International Livestock Research Centre for Africa, Addis Ababa, Ethiopia

Tisdale, S. T., Nelson, W. L. and J. D. Beaton, J. D. 1985. Soil Fertility and Fertilizers. 4 th ed. Macmillan Publishing Company, New York. 499p.

Van Reeuwijk LP. 1992.Procedure for soil analysis.3rdEd.International Soil Reference and Information Center, Wageningen (ISRIC).The Netherlands. AJ Wageningen.

Wang, J., Raman, H., Zhang, G. Mendham, N. and Zou, M. 2006. Aluminum tolerance in barely 5(Horidiumvulgarie L.): Physiological mechanisms, genetics and screening methods. Journal of Zhejiang University Science. 7: 769-787. 